Proceeding Paper

\title{
Assessment of Embodied Energy and Environmental Impact of Sustainable Building Materials and Technologies for Residential Sector ${ }^{\dagger}$
}

\author{
Muhammad Mahboob ${ }^{1, * D}$, Muzaffar Ali ${ }^{1}$, Tanzeel ur Rashid ${ }^{1}$ and Rabia Hassan ${ }^{2}$ (D) \\ 1 Department of Mechanical Engineering, UET, Taxila 47080, Pakistan; muzaffar.ali@uettaxila.edu.pk (M.A.); \\ Tanzeel.ur.rashid@uettaxila.edu.pk (T.u.R.) \\ 2 College of Engineering and Sciences, Institute of Business Management, Karachi 74000, Pakistan; \\ rabia.hassan@iobm.edu.pk \\ * Correspondence: Muhammad.Mahboob14140@gmail.com \\ + Presented at the 1st International Conference on Energy, Power and Environment, Gujrat, Pakistan, \\ 11-12 November 2021.
}

Citation: Mahboob, M.; Ali, M.; Rashid, T.u.; Hassan, R. Assessment of Embodied Energy and

Environmental Impact of Sustainable Building Materials and Technologies for Residential Sector. Eng. Proc. 2021, 12, 62. https://doi.org/10.3390/ engproc2021012062

Academic Editor: Shahid Iqbal

Published: 30 December 2021

Publisher's Note: MDPI stays neutral with regard to jurisdictional claims in published maps and institutional affiliations.

Copyright: (C) 2021 by the authors. Licensee MDPI, Basel, Switzerland. This article is an open access article distributed under the terms and conditions of the Creative Commons Attribution (CC BY) license (https:// creativecommons.org/licenses/by/ $4.0 /)$.

\begin{abstract}
The energy demand of developing countries increases every year. Large amounts of energy are consumed during the production and transportation of construction materials. Conservation of energy became important in the perspective of limiting carbon emissions into the environment and for decreasing the cost of materials. This article is concentrated on some issues affecting the embodied energy of construction materials mainly in the residential sector. Energy consumption in three various wall structures has been made. The comparison demonstrated that the embodied energy of traditional wall structures is 3-times higher than the energy efficient building materials. $\mathrm{CO}_{2}$ emissions produced by conventional materials and green building materials are $54.96 \mathrm{Kg} \mathrm{CO}_{2} / \mathrm{m}^{2}$ and $35.33 \mathrm{Kg}$ $\mathrm{CO}_{2} / \mathrm{m}^{2}$, respectively. Finally, the results revealed substantial difference in embodied energy and carbon footprints of materials for which its production involves a high amount of energy consumption.
\end{abstract}

Keywords: embodied energy; sustainable materials; carbon emissions

\section{Introduction}

The rapidly growing global energy consumption over last two decades is alarming and it significantly influenced the energy sector by depleting energy resources [1]. The world's overall energy consumption has increased by $30 \%$ during last twenty-five years [2]. The building sector, by utilizing 30 to $40 \%$ of world energy resources, stands third in ranking after industrial and agriculture sectors [3]. In January, the 2008 European Commission (EC) formulated a Climate Action Package with the aim to preserve global energy and control Green House Gas (GHG) emissions by increasing the share of renewable energy resources up to $20 \%$ by the end of year 2020 [4]. Globally, many residential energy policies are framed for presenting different energy saving programs by signifying numerous potential areas and loop holes [5,6]. As the housing sector is the major consumer of world's primary and secondary energy, suitable energy-efficient strategies are, therefore, required, particularly in this sector.

\section{Literature Review}

There are many articles on embodied energy of building materials that mainly relate to different methods of assessment, gathering embodied energy of different building materials and examining other features that affect the assessment of embodied energy. Various research revealed that embodied energy can be determined by conducting different experiments or analysis. The report [7] highlighted the factors affecting embodied energy, which includes various boundary conditions for a system. Basbagill, J. [8] shows that 
operational energy of building consumes $80 \%$ of the total energy throughout the life cycle of a conventional building. Mpakati-Gama [9] made a comparison between current data and different approaches for determining the embodied energy and $\mathrm{CO}_{2}$ footprints of buildings.

Based on the literature review, it is important to find the embodied energy of different materials, especially sustainable materials that could play important roles in reducing building energy and also reducing carbon emissions.

\section{Embodied Energy}

In building sector, the consumption of energy can be divided into two categories. Energy consumed during mining, transportation, manufacturing process of raw materials, assembling and maintenance is known as embodied energy. Operational energy is the energy required for building during its lifetime from commission to destruction. Embodied energy makes up practically $20 \%$ of total building energy.

\subsection{Assessing of Embodied Energy}

The embodied energy of a building can be assessed through various processes:

- $\quad$ Energy used to transport the raw material on site and number of workers used to build the site;

- Only constructional material or other fittings used in the building such as kitchen or bathroom fitting, etc.;

- Upstream energy inputs for making materials such as factory, lightening or energy used on machine for maintenance and manufacturing materials.

- Embodied energy for urban infrastructure such as roads, drains, water and energy supply.

\subsection{Embodied Energy of Basic Building Materials}

Cement, lime, glass, steel and aluminum are used as basic building materials. The embodied energy $(\mathrm{MJ} / \mathrm{kg})$ and $\mathrm{CO}_{2}\left(\mathrm{KgCO}_{2} / \mathrm{kg}\right)$ emissions produced are shown in the Table 1.

Table 1. Embodied energy and $\mathrm{CO}_{2}$ emissions of basic building materials.

\begin{tabular}{ccc}
\hline Material & EE (MJ/Kg) & CE $\left(\mathrm{KgCO}_{2} / \mathbf{K g}\right)$ \\
\hline Cement & 4.6 & 0.83 \\
Lime & 5.3 & 0.74 \\
Glass & 15 & 0.85 \\
Aluminum & 155 & 8.24 \\
Steel & 24.4 & 1.74 \\
\hline
\end{tabular}

\section{Results and Discussion}

\subsection{Conventional Building Materials}

Masonry walls are the major energy consuming component of buildings. Different materials are used for walls such as clay brick, hollow blocks, AAC blocks and soil cement block. In this study, the main focus is to compare embodied energy and carbon emissions of different kinds of wall structures during the construction of buildings.

\subsection{Embodied Energy of Conventional Building Materials}

Conventional clay bricks, low weight hollow concrete blocks and highly thermally insulated Auto Clave aerated concrete blocks are used for building construction. The EE and $\mathrm{CO}_{2}$ emissions of conventional building materials are shown in Table 2. 
Table 2. Embodied energy and $\mathrm{CO}_{2}$ emissions of masonry materials.

\begin{tabular}{|c|c|c|c|c|c|c|}
\hline Material & Size $(\mathrm{mm})$ & $\begin{array}{c}\Phi \\
\left(\mathrm{Kg} / \mathrm{m}^{3}\right)\end{array}$ & $\begin{array}{c}\mathrm{EE} \\
(\mathrm{MJ} / \mathrm{kg})\end{array}$ & $\begin{array}{c}\mathrm{EE} \\
\left(\mathrm{MJ} / \mathrm{m}^{2}\right)\end{array}$ & $\begin{array}{c}\mathrm{CE} \\
\left(\mathrm{CO}_{2} \mathrm{Kg} / \mathrm{Kg}\right)\end{array}$ & $\begin{array}{c}\mathrm{CE} \\
\left(\mathrm{CO}_{2} \mathrm{Kg} / \mathrm{m}^{2}\right)\end{array}$ \\
\hline Clay Brick & $76 \times 29 \times 114$ & 1800 & 3 & 600 & 0.22 & 45.14 \\
\hline Hollow Block & $203 \times 406 \times 114$ & 725 & 0.95 & 78.5 & 0.129 & 10.66 \\
\hline AAC Blocks & $203 \times 610 \times 114$ & 600 & 3.5 & 220.5 & 0.28 & 19.15 \\
\hline
\end{tabular}

\subsection{Embodied Energy of Sustainable Materials/Technologies}

Thermal insulations are used in wall structures to reduce heat losses throughout the year. Thermal insulations used in construction material are shown in Table 3.

Table 3. Embodied energy and $\mathrm{CO}_{2}$ emissions of thermal insulations.

\begin{tabular}{cccccc}
\hline Material & $\boldsymbol{\varphi ( \mathrm { Kg } / \mathbf { m } ^ { \mathbf { 3 } } )}$ & $\mathrm{EE} \mathrm{(MJ/Kg)}$ & $\mathrm{EE}\left(\mathbf{M J} / \mathbf{m}^{\mathbf{2}}\right)$ & $\begin{array}{c}\mathrm{CE} \\
\left(\mathrm{CO}_{\mathbf{2}} \mathbf{K g} / \mathbf{K g}\right)\end{array}$ & $\begin{array}{c}\mathrm{CE} \\
\left(\mathrm{CO}_{\mathbf{2}} \mathbf{K g} / \mathbf{m}^{2}\right)\end{array}$ \\
\hline Expanded & 20 & 109.2 & 55.47 & 3.4 & 1.73 \\
Polystyrene & 30 & 72.1 & 54.94 & 3 & 2.29 \\
Polyurethane & 60 & 16.6 & 25.29 & 1.2 & 1.83 \\
Mineral Wool & 12 & 28 & 8.53 & 1.35 & 0.41 \\
Fiberglass & 12 & &
\end{tabular}

\subsection{Case 1: Clay Brick Walls with Thermal Insulations}

Total embodied energy and carbon emission produced for different wall structures are calculated in this section and shown in Table 4.

Table 4. Total embodied energy and $\mathrm{CO}_{2}$ emissions of brick wall structure.

\begin{tabular}{|c|c|c|c|c|c|}
\hline Material & $\begin{array}{c}\text { Thickness } \\
(\mathrm{mm})\end{array}$ & EE (MJ/Kg) & $\mathrm{EE}\left(\mathrm{MJ} / \mathrm{m}^{2}\right)$ & $\begin{array}{c}\mathrm{CE} \\
\left(\mathrm{CO}_{2} \mathrm{Kg} / \mathrm{Kg}\right)\end{array}$ & $\begin{array}{c}\mathrm{CE} \\
\left(\mathrm{CO}_{2} \mathrm{Kg} / \mathrm{m}^{2}\right)\end{array}$ \\
\hline Clay Brick & 114 & 3 & 600 & 0.22 & 45.14 \\
\hline Internal Plaster & 20 & 1.55 & 58.9 & 0.213 & 8.09 \\
\hline External Plaster & 20 & 1.55 & 58.9 & 0.213 & 8.09 \\
\hline Polystyrene & 25 & 109.2 & 55.47 & 3.4 & 1.73 \\
\hline Polyurethane & 25 & 72.1 & 54.94 & 3 & 2.29 \\
\hline Total (1-4) & 179 & 115.3 & 773.27 & 4.05 & 63.05 \\
\hline Total (1-3 and 5) & 179 & 78.2 & 772.74 & 3.65 & 63.61 \\
\hline
\end{tabular}

\subsection{Case 2: Hollow Concrete Block Wall Structure with Thermal Insulation}

In this section, embodied energy and carbon emissions of hollow concrete block wall structure are calculated and detailed shown in Table 5.

Table 5. Total embodied energy and $\mathrm{CO}_{2}$ emissions of hollow block wall structure.

\begin{tabular}{cccccc}
\hline Material & $\begin{array}{c}\text { Thickness } \\
(\mathbf{m m})\end{array}$ & EE (MJ/Kg) & EE (MJ/m $\left.\mathbf{~}^{\mathbf{2}}\right)$ & $\begin{array}{c}\mathbf{C E} \\
\left(\mathbf{C O}_{\mathbf{2}} \mathbf{K g} / \mathbf{K g}\right)\end{array}$ & $\begin{array}{c}\mathbf{C E} \\
\left(\mathbf{C O} \mathbf{K g} / \mathbf{m}^{\mathbf{2}}\right)\end{array}$ \\
\hline Hollow Block & 114 & 0.95 & 78.5 & 0.129 & 10.66 \\
Internal Plaster & 20 & 1.55 & 58.9 & 0.213 & 8.09 \\
External Plaster & 20 & 1.55 & 58.9 & 0.213 & 8.09 \\
Polystyrene & 25 & 109.2 & 55.47 & 3.4 & 1.73 \\
Polyurethane & 25 & 72.1 & 54.94 & 3 & 2.29 \\
Total (1-4) & 179 & 113.25 & 251.77 & 3.95 & 28.57 \\
Total (1-3 and 5) & 179 & 76.15 & 251.24 & 3.55 & 29.13 \\
\hline
\end{tabular}




\subsection{Case 3: AAC Block Wall Structure with Thermal Insulation}

In this section, embodied energy and $\mathrm{CO}_{2}$ emissions of $\mathrm{AAC}$ block wall structure with thermal insulation are calculated and brief detailed shown in Table 6.

Table 6. Total embodied energy and $\mathrm{CO}_{2}$ emissions of AAC block wall structure.

\begin{tabular}{|c|c|c|c|c|c|}
\hline Material & $\begin{array}{c}\text { Thickness } \\
\text { (mm) }\end{array}$ & $\mathrm{EE}(\mathrm{MJ} / \mathrm{Kg})$ & $\mathrm{EE}\left(\mathrm{MJ} / \mathrm{m}^{2}\right)$ & $\begin{array}{c}\mathrm{CE} \\
\left(\mathrm{CO}_{2} \mathrm{Kg} / \mathrm{Kg}\right)\end{array}$ & $\begin{array}{c}\mathrm{CE} \\
\left(\mathrm{CO}_{2} \mathrm{Kg} / \mathrm{m}^{2}\right)\end{array}$ \\
\hline AAC Block & 114 & 3.5 & 220.5 & 0.28 & 19.15 \\
\hline Internal Plaster & 20 & 1.55 & 58.9 & 0.213 & 8.09 \\
\hline External Plaster & 20 & 1.55 & 58.9 & 0.213 & 8.09 \\
\hline Polystyrene & 25 & 109.2 & 55.47 & 3.4 & 1.73 \\
\hline Polyurethane & 25 & 72.1 & 54.94 & 3 & 2.29 \\
\hline Total (1-4) & 179 & 115.8 & 292.15 & 4.106 & 37.06 \\
\hline Total (1-3 and 5) & 179 & 78.7 & 291.68 & 3.706 & 37.62 \\
\hline
\end{tabular}

Total embodied energy and carbon emissions for clay brick wall structure are higher than the other two wall structures. The hollow block has the lowest embodied energy because of its raw material and manufacturing process. The AAC block has much higher embodied energy, but it is more suitable due to its low thermal conductivity and high bearing strength. Table 7 gives the detailed information about $\mathrm{EE}$ and $\mathrm{CO}_{2}$ emissions of various wall structures.

Table 7. Total embodied energy and $\mathrm{CO}_{2}$ emissions of all wall structures.

\begin{tabular}{ccc}
\hline Material & Total EE $\left(\mathbf{M J} / \mathbf{m}^{\mathbf{2}}\right)$ & Total CE $\left(\mathbf{K g} / \mathbf{m}^{\mathbf{2}}\right)$ \\
\hline Clay Brick & 718 & 55 \\
Hollow Blocks & 197 & 27 \\
AAC Blocks & 339 & 36 \\
\hline
\end{tabular}

\section{Conclusions}

The current study deals in depth with assessment of embodied energy and carbon footprints of various building materials. Comparison between various wall structures indicates that conventional building materials such as clay brick have higher embodied energy and also produce higher amount of carbon emissions. For energy efficiency and environmentally friendly conditions, AAC blocks are used as sustainable materials for buildings. With the integration of thermal insulation materials on different wall structures, energy consumption can be reduced. A residential building contains normal 1000 GJ of energy embodied in material utilized in construction that is equivalent to right around 15 years typical operational energy.

Funding: This research received no external funding.

Institutional Review Board Statement: Not applicable.

Informed Consent Statement: Not applicable.

Data Availability Statement: Not applicable.

Conflicts of Interest: The authors declare no conflict of interest.

\section{References}

1. Akadiri, P.O.; Chinyio, E.A.; Olomolaiye, P.O. Design of a sustainable building: A conceptual framework for implementing sustainability in the building sector. Buildings 2012, 2, 126-152. [CrossRef]

2. Chel, A.; Kaushik, G. Renewable energy technologies for sustainable development of energy efficient building. Alex. Eng. J. 2017, 57, 655-669. [CrossRef]

3. Evans, M.; Roshchanka, V.; Graham, P. An international survey of building energy codes and their implementation. J. Clean. Prod. 2017, 158, 382-389. [CrossRef] 
4. Rauf, O.; Wang, S.; Yuan, P.; Tan, J. An overview of energy status and development in Pakistan. Renew. Sustain. Energy Rev. 2015, 48, 892-931. [CrossRef]

5. Karunathilake, H.; Hewage, K.; Sadiq, R. Opportunities and challenges in energy demand reduction for Canadian residential sector: A review. Renew. Sustain. Energy Rev. 2017, 82, 2005-2016. [CrossRef]

6. Sarkar, A.; Bose, S. Exploring impact of opaque building envelope components on thermal and energy performance of houses in lower western Himalayans for optimal selection. J. Build. Eng. 2016, 7, 170-182. [CrossRef]

7. Nassen, J.; Holmberg, J.; Wadeskog, A.; Nyman, M. Direct and indirect energy use and carbon emissions in the production phase of buildings: An input-output analysis. Energy 2017, 32, 1593-1602. [CrossRef]

8. Basbagill, J.; Flager, F.; Lepech, M.; Fischer, M. Application of life-cycle assessment to early stage building design for reduced embodied environmental impacts. Build. Environ. 2013, 60, 81-92. [CrossRef]

9. Mpakati-Gama, E.C.; Brown, A.; Sloan, B. Embodied energy and carbon analysis of urban residential buildings in Malawi. Int. J. Constr. Manag. 2016, 16, 1-12. [CrossRef] 